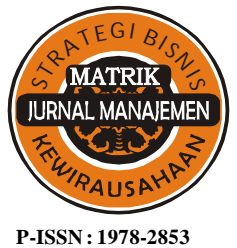

E-ISSN : 2302-8890

\section{MATRIK: JURNAL MANAJEMEN, STRATEGI BISNIS DAN KEWIRAUSAHAAN}

Homepage: https://ojs.unud.ac.id/index.php/jmbk/index

Vol. 14 No. 1, Februari 2020, 22 - 32

\title{
Developing A Model with Dematel, Anp, Topsis Approaches for Marketing Strategy Selection in Batik Madura Industry
}

\author{
Indra Cahyadi \\ University of Trunojoyo Madura \\ email: indra.cahyadi@trunojoyo.ac.id
}

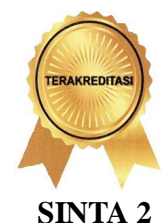

DOI : https://doi.org/10.24843/MATRIK:JMBK.2020.v14.i01.p03

\begin{abstract}
The selection of marketing strategy is very important for the sustainability of small and medium enterprises (SMEs). Choosing the best marketing strategy is a process involving problem of multiple decision-making criteria, which considers many attributes in various phases of a strategy formulation method. This paper proposes a model of selecting marketing strategy for Batik Madura SMEs. The model selected five criteria including customer networking, innovation capabilities, managerial competency, human capital, and company reputation based on literature reviews and focus group decision-making discussion. Analytic network process (ANP), decision-making trial and evaluation laboratory (DEMATEL) and technique for order preference by similarity to an ideal solution (TOPSIS) methods were applied to obtain an impact relation map from each criteria and to determine the priority of marketing strategy. The implementation of the model shows that Batik Madura SMEs should maintain their focus on segmentation marketing as the most appropriate marketing strategy.
\end{abstract}

Keywords: Batik madura, marketing strategy, multiple criteria decision making, small and medium enterprises

\section{Mengembangkan Model dengan Pendekatan Dematel, Anp, Topsis untuk Pemilihan Strategi Pemasaran di Industri Batik Madura}

\begin{abstract}
ABSTRAK
Pemilihan strategi pemasaran sangat penting untuk keberlanjutan usaha kecil dan menengah (UKM). Memilih strategi pemasaran terbaik adalah masalah yang melibatkan proses pengambilan keputusan multi kriteria, yang mempertimbangkan banyak atribut dalam berbagai fase metode perumusan strategi. Makalah ini mengusulkan model untuk memilih strategi pemasaran di UKM Batik Madura. Model dalam penelitian ini memilih lima kriteria termasuk jaringan pelanggan, kemampuan inovasi, kompetensi manajerial, modal manusia, dan reputasi perusahaan berdasarkan hasil tinjauan pustaka dan diskusi pengambilan keputusan kelompok fokus. Hasil dari proses jaringan analitik (ANP), percobaan pengambilan keputusan dan evaluasi laboratorium (DEMATEL) dan Teknik untuk preferensi pesanan dengan kemiripan dengan metode solusi ideal (TOPSIS) diterapkan untuk memperoleh peta hubungan dampak dari setiap kriteria dan untuk menentukan prioritas strategi pemasaran. Implementasi model menunjukkan bahwa UKM Batik Madura harus mempertahankan fokus mereka pada pemasaran segmentasi sebagai strategi pemasaran yang paling tepat.
\end{abstract}

Kata kunci: Batik madura, strategi pemasaran, pengambilan keputusan multi kriteria, usaha kecil dan menengah

\section{INTRODUCTION}

The economic development in Madura depends on small and medium enterprises (SMEs) and creative industries such as batik industry. In particular, Batik Madura SMEs have high potential to boost employment rate and income of the Madura's people. Batik Madura is famous for its unique colorful pattern and has been already marketed through extensive international and domestic trade exhibitions. Furthermore, businesses of Batik Madura have transformed from familyowned outlets into a more structured business entities.

As an anticipation of the ASEAN Economic Community (AEC) implementation in 2020 and the international trade globalization, batik Madura SMEs need to improve their competitiveness and optimize their business process. This international phenomenon actually àhave forced batik Madura SMEs to meet regional and international customers' trend and demand. However, uncertain customer 
demands of textile industry make marketing prediction difficult (Lo and Hong, 2012). Batik SMEs endure high level of competition, which influences their product prices. It makes them highly dependent to their market trends and customer demands (Soekesi, 2013). Product types in the fashion market are widely different from one location to another because the product typically has a short life cycle. In order to fulfill consumer demands and maintain better chances to compete, fashion industries must choose and develop their marketing strategy carefully (Ernst et al., 2010). According to those articles, (hapus) Batik Madura SMEs as fashion creative industries require a method to effectively and efficiently select their products marketing strategy.

There are many challenges, such as fierce competition and fluctuating market, which can shrink batik Madura SMEs' profits and hinder their business sustainability. Batik Madura SMEs would have gone out of business or switched to other business types if they could not sustain their product's marketability. Choosing the right strategies will support batik Madura SMEs to survive in a highly competitive fashion and textile business. It is expected that the right marketing strategy will increase the operational efficiency and improve the existing supply chain business process of the parties involved in the batik industries. By doing this, batik Madura SMEs will be able to survive in global market and maintain their profitability.

Marketing is considered as an investment that can make a simultenous improvement in pursuit of improved business sustainability and customer perceptions. A typology of three generic strategiesincluding overall cost leadership, differentiation, and focus for creating a sustainable position and outperforming competitors is basic marketing knowledge that must be understood and implemented by SMEs managers (Marek, 2014). Another marketing strategy emerged from the rapid development of social media and their penetration in customer-focused marketing actions is peoplebased network marketing (Van de Bulte, 2010). However, marketing is often view as a critical factor in small business situations, when there is often limited money, time, and human resources talent to establish a presence in a overcrowded global market place. According to Lin et al., 2010 and Hooley et al., 2005 there are five marketing resources required to determine the optimal marketing strategy for small businesses. They are customer networking, innovation capabilities, managerial competency, human capital, and company reputation. These criteria of marketing strategy can be utilized to determine the fuzzy weights of criteria and sub-criteria and assert various weights in a hierarchical marketing strategy structure (Mohaghar et al., 2010).

Therefore, marketing strategies desision making process will support SMEs effort to survive in the current highly competitive business environment. Previous research pinpointed the problems and formulated the competitive strategy for Purbalingga Batik, using an Analytical Hierarchy Process (AHP) (Suliyanto, 2010). There are five business constraints in Purbalingga Batik. They are marketing, human resources, financial, operational, business environment. The article identified that human resources development in Purbalingga Batik was affected by lack of proper management, lack of regeneration, lack of manpower, low productivity, and the emergence of machine-intensive industries. According Mohaghar et al., 2010, the SMEs managerial capabilities are determined based on the organization's market innovation capabilities and human resource assets. For SMEs to pursue customers' satisfaction, SMEs management should attempt to promote the specific capabilities for product/market innovation. In addition, in order to improve the innovation capabilities, SMEs management should strengthen the employees' creative abilities for product, service and cooperate with novel managerial process and implementation. Indeed, SMEs entrepreneurs' vision and proactive attitude to maintain their business sustainability is very important (Cahyadi, 2016). SMEs owners who have vision, experience and knowledge in managing new business opportunities will be able to take advantage of new market niches through innovative products tailor made to meet the needs of that market. While, proactive attitude to an increasingly uncertain business environment will keep a SME to remain competitive in the market.

In order to determine the priority of marketing strategy for batik Madura SMEs, this research proposes four marketing strategies based on focus, cost leadership, differentiation strategy, and peoplebased network marketing. Since there are many criteria involved in selecting appropriate marketing strategy, this research employs multi criteria decision making method to draw an impact relation map from each criteria. The result of multi criteria decision making method will be used to determine batik 
Madura SMEs marketing strategy priority. The optimal marketing strategy for Batik Madura SMEs can be determined based on the available selection criteria and the largest weight of among alternative marketing strategies.

\section{RESEARCH METHOD}

Based on the research model, a survey questionnaire was distributed to a sample frame drawn from local Government Agency of Cooperative and SMEs database and Madura creative industries user members' directories. The invitations to participate in survey questionnaires were sent by email and a focus group discussion (FGD) involving relevant stakeholders of SMEs development in Madura was held to determine the marketing strategy criteria and their alternatives. The population in this study are all batik SMEs in Madura. For the collection of primary data, a purposive sampling (non-probability sampling) was employed to gather data from 56 respondents. The FGD was attended by 5 respondents as representatives from batik SMEs, the Local Agency for Cooperatives and Micro, Small and Medium-sized Enterprises (Dinas Koperasi dan Usaha Mikro, Kecil, dan Menengah/ DISKOP-UMKM), the Local Agency for Industry and Trade Services (Dinas Perindustrian dan
Perdagangan/DISPERINDAG) from Bangkalan, Pamekasan and Sumenep.

The discussion and survey results were employed to chart the interrelationships between the marketing selection criteria and the strategy alternatives. Analytical Network Process (ANP) methodology was used in model development that reflects the relationships between selection criteria in Batik Madura SMEs marketing strategy (Saaty, 1996).

ANP uses a network map to describe the priorities in a system based on interdependency and feedback. The ANP network map also produces a structured influence network of criteria among clusters and nodes. Clusters are groups of indicators for criteria classification while nodes are criteria or indicators for the model construction. In order to develop the framework of the problem, pair-wise comparisons matrix would be constructed to evaluate all the interactions among the elements. Moreover, priority vectors would be calculated to obtain a super matrix of the influences among the elements. This super matrix is derived from the inclusion of priority vectors to obtain overall priorities in a system involving interdependent influences of elements on each other. When the criteria are interrelated, the entry of super matrix of a hierarchy of $n$ given would indicate the interdependency, and the super matrix is as follows

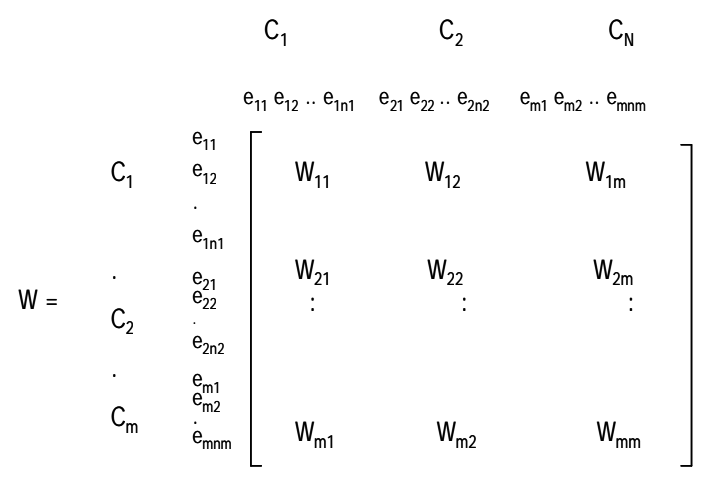

Since $\mathrm{W}$ entries are composed of the vectors entered from the pair-wise comparisons, $\mathrm{W}$ is a partitioned matrix with the columns of a super matrix usually total more than one. Therefore, each column of the matrix needs to sum to unity and the super matrix must be transformed to form a column stochastic matrix. In order to obtain the global priority vectors, the limiting value is calculated by raising W to powers (Saaty and Vargas, 1996).

$$
\lim _{k \rightarrow \infty} W^{k}
$$

Once, the super matrix is transformed into a column stochastic matrix, it is raised to a achieve convergence of the importance weights (Saaty, 1996). The super matrix is raised to the power of $2 k+1$, where $\mathrm{k}$ is an arbitrarily large number. In other words, the supermatrix limiting powers now becomes $W^{2 k+1}$. Normalizing each block of this super matrix can capture all the interactions and obtain the final priorities of all elements in the matrix.

The analytic network process (ANP), decisionmaking trial and evaluation laboratory (DEMATEL) 
model was developed to each cluster, each element and assigned to their inter relationships (Fontela and Gabus, 1974). Calculation of super matrix, which is the inter relationship that influences the criteria between the partitioned matrix, was performed to make a list of batik Madura SMEs priority over certain marketing strategy. The procedures of the DEMATEL method can be expressed as follow:

$$
\left[a_{i j}\right]_{n x n}=\frac{1}{h} \sum_{k=1}^{H}\left[x_{i j}^{k}\right]_{n x n}
$$

Step 2: Calculate a normalized matrix from the initial direct-relation matrix. The normalized initial direct-relation matrix $D=\left[d_{i j}\right]$, where each element $d i j$ of matrix $D$ is between zero and less

$$
\begin{aligned}
& S=\max \left\{\max \sum_{j=1}^{n} a_{i j}, \max \sum_{i=1}^{n} a_{i j}\right\} \\
& D=\frac{A}{S}
\end{aligned}
$$

Step 3: Derive the total-relation matrix. The total-relation matrix $\mathrm{T}$ where each element of $t_{i j}$ reflects the indirect effects that criterion $i$ had on

$$
\begin{aligned}
\sum_{m=1}^{\infty} D_{i} & =D+D^{2}+D^{3}+\cdots+D^{m} \\
& =D\left(I+D+D^{2}+\cdots+D^{m-1}\right) \\
& =D(I-D)^{-1}(I-D)\left(I+D+D^{2}+\cdots+D^{m-1}\right)=D(I-D)^{-1}\left(I-D^{m}\right) \\
& =D(I-D)^{-1}
\end{aligned}
$$

than 1: $0<d i j<1$. Normalized matrix $\mathrm{D}$ is obtained by normalizing the average matrix A. The calculation is shown below: criterion $j$ and represents the relationship between each pair of criteria. The total relation matrix $T_{n x n}$. is obtained by utilizing:
Step 1: Determine the direct-relation, average matrix. The values of relationships between different criteria are determined according to the experts' opinion. The $n \times n$ average matrix $\mathrm{A}$, or the initial direct-relation matrix, is calculated based on all expert's opinions by averaging the $\mathrm{H}$ of their scores as follows:
Step 4: Compute the sums of rows and columns of the total-relation matrix T. In the total-relation

$$
\begin{aligned}
r & =\left[r_{i}\right]_{n x 1}=\left(\sum_{j=1}^{n} t_{i j}\right)_{n x 1} \\
& =\left[c_{j}\right]_{1 x n}^{\prime}=\left[\sum_{j=1}^{n} t_{i j}\right]_{1 x n}
\end{aligned}
$$

matrix T, vectors $r$ and $c$ represent the sum of rows and the sum of columns, respectively.
Where $r=\left[r_{i}\right]$ represents the total effects, both direct and indirect, given by criterion to the other criteria and is denoted as transposition matrix that demonstrates total effects, direct and indirect, received by criterion from the other criteria. 
In order to determine the ideal solution and the appropriate strategy for the problem, the TOPSIS methodology was employed using the output from ANP and DEMATEL model to determine the closest to the ideal solution as the preferred selection and to find farthest value as the negative-ideal solution in a multidimensional computing matrix. TOPSIS method pick alternatives which have the farthest distance from the negative-ideal solution and the

$$
\begin{gathered}
r_{i j}=x_{i j} \sqrt{\sum_{i=1}^{m} x_{i j}^{2}} \\
i=1,2, \ldots, m \text { and } j=1,2, \ldots, 3
\end{gathered}
$$

shortest distance from the positive-ideal solution (Hwang and Yoon, 1981). The process TOPSIS method comprises of these following steps:

Step 1: Calculate the normalized decision matrix. This step allows comparisons across criteria by transforming attribute dimensions into nondimensional attributes. The normalized $r_{i j}$ value is calculated as follows:
Step 2: Calculate the weighted normalized decision matrix. Multiply each column of the normalized decision matrix by its associated weight. The weighted normalized value $v_{i j}$ is calculated as follows:

$$
\begin{aligned}
v_{i j} & =r_{i j} x w_{i j} \\
i & =1,2, \ldots, m \text { and } j=1,2, \ldots n
\end{aligned}
$$

Where $w_{j}$ is the weight of the $j^{\text {th }}$ criterion or attribute and $\sum_{j=1}^{n} w_{j}=1$

Step 3: Determine the positive-ideal $\left(A^{*}\right)$ and negative $\left(A^{-}\right)$solutions.

$$
\begin{aligned}
& A^{*}=\left\{\left(\max _{i} v_{i j} \mid j \epsilon C_{b}\right),\left(\min _{i} v_{i j} \mid j \epsilon C_{c}\right)\right\}=\left\{v_{j}^{*} \mid j=1,2, \ldots, m\right\} \\
& A^{-}=\left\{\left(\min _{i} v_{i j} \mid j \epsilon C_{b}\right),\left(\max _{i} v_{i j} \mid j \epsilon C_{c}\right)\right\}=\left\{v_{j}^{-} \mid j=1,2, \ldots, m\right\}
\end{aligned}
$$

where $C_{b}$ is related with benefit criteria and $C_{c}$ is related with cost criteria

Step 4: Using the m-dimensional Euclidean distance, calculate the separation measures. The

$$
\begin{gathered}
S_{i}^{*}=\sqrt{\sum_{j=1}^{m}\left(v_{i j}-v_{j}^{*}\right)^{2}, j=1,2, \ldots, m} \\
S_{i}^{-}=\sqrt{\sum_{j=1}^{m}\left(v_{i j}-v_{j}^{-}\right)^{2}, j=1,2, \ldots, m}
\end{gathered}
$$

separation measures of each alternative from the positive ideal solution and the negative ideal solution, respectively, are given as:
Step 5: Calculate the relative closeness to the ideal solution. Choose the option with $R C_{i}^{*}$ value

$$
R C_{i}^{*}=\frac{S_{i}^{-}}{S_{i}^{*}+S_{i}^{-}}, i=1,2, \ldots, m
$$

closest to 1 . The relative closeness of the alternative $A_{j}$ with respect to $\mathrm{A}^{*}$ is calculated as follows: 
Step 6: Rank the preference order.

The index values of $R C_{i}$ lie between 0 and 1 . the closest solution to ideal for alternatives is the one with the largest index value.

\section{RESULTS AND DISCUSSION}

The results of previous studies and expert group discussion have guided the development of the model of inter relationship influences between criteria and marketing strategy. In this study, five main criteria were included: customer networking $(\mathrm{SCN})$, innovation capabilities (SIC), managerial competency (MAC), human capital (HRC), and company reputation (SCR).

Customer networking in SMEs refers to the process of network building developed by SME owners-managers in managing business activities with their customers (Wu et al., 2010), (De Jong and Hulsink, 2012). In fact, the benefit of networking is enable to build trust relationships among businesses (De Jong and Hulsink, 2012). Furthermore, SMEs harvest from individual ties in their networks, including suppliers, customers, friends and relatives, for various purposes (Danis et al., 2010). Therefore, customer networking relates to level of customer service (SCN1), relationship with the key target customers (SCN2), understanding customer's need (SCN3), creating relationship with new customers (SCN4), maintaining relationship with returning customers (SCN5) (Lin et al., 2009), (Hooley et al., 2005), (Wu et al., 2010), and (De Jong and Hulsink, 2012).

SMEs' innovation capability (SIC) can be defined as the collection of interrelated process and routines SMEs have in place for carrying out innovation related activities such as improving production longevity, improving product quality, developing new products, expanding product ranges and implementing the current technologies in their daily business activities (O'Cass and Ngo, 2012). In this study, SMEs' innovation capabilities are measured through employees' creative abilities (SIC1), novel managerial process (SIC2), promotion and implementation of product innovation (SIC3) (Lin et al., 2009), (Hooley et al., 2005), (Wu et al., 2010), and (O'Cass and Ngo, 2012).

This study considers managerial competency as a set of measurable attributes of an employee that is critical for exhibiting effective performance in a specific job in organization or company (Sengupta, 2013). These attributes are defined in terms of ability in managing finance (MAC1), ability to handle daily business activities (MAC2), and ability to deal with human resources capital (MAC3) (Lin et al., 2009), (Hooley et al., 2005), (Wu et al., 2010), and (Sengupta, 2013). These competencies are behavioral, and can be developed through time.

Human capital management relates to the personal responsibility and actions taken by the SMEs owner managers in managing their employee to foster the culture of innovation and sustainability in their firm (Halim et al., 2014). This study includes sub-criteria of proper craftsmen regeneration (HRA1) and availability of craftsmanship (HRA2) to examine human capital criteria in the proposed model (Lin et al., 2009), (Hooley at al, 2005), (Wu et al., 2010), and (Halim, 2014).

In this research, SMEs reputation has been identified as a criteria that relates to all objects that could influence the representation of a SMEs in the past and future and relevant in particular to SMEs brand equity (Kazlauskaitë et al., 2015), (Sok and O'Cass, 2011). Company reputation has commonly measured by examining brand name/reputation (SCR1) and credibility with customers (SCR2) (Lin et al., 2009), (Hooley et al., 2005), (Kazlauskaitë et al., 2015), and (Sok and O'Cass, 2011).

A focus group discussion was initiated to develop the structure and interelationship of the selection criteria of Batik Madura SMEs marketing strategy options. The results of questionnaire and discussion with the experts of Batik Madura SMEs were used to map an inter relationship between the criteria to select the best marketing strategy and then further developed as the proposed model for this study. The resulting map given in Fig. 1 from which the interrelationship among the fourteen criteria can be determined.

According to experts opinions through DEMATEL analysis, almost all criteria are mutually interrelated. Figure 1 is a network of relationships between criteria that influence each other. The relationship can be seen based on the direction of each arrow. For example, innovation influences SMEs' effort to retain old customer, capture customer needs, identify key customer, and attract new customer. Proper craftsmen regeneration has impact on craftsmen availability, SMEs' finance 


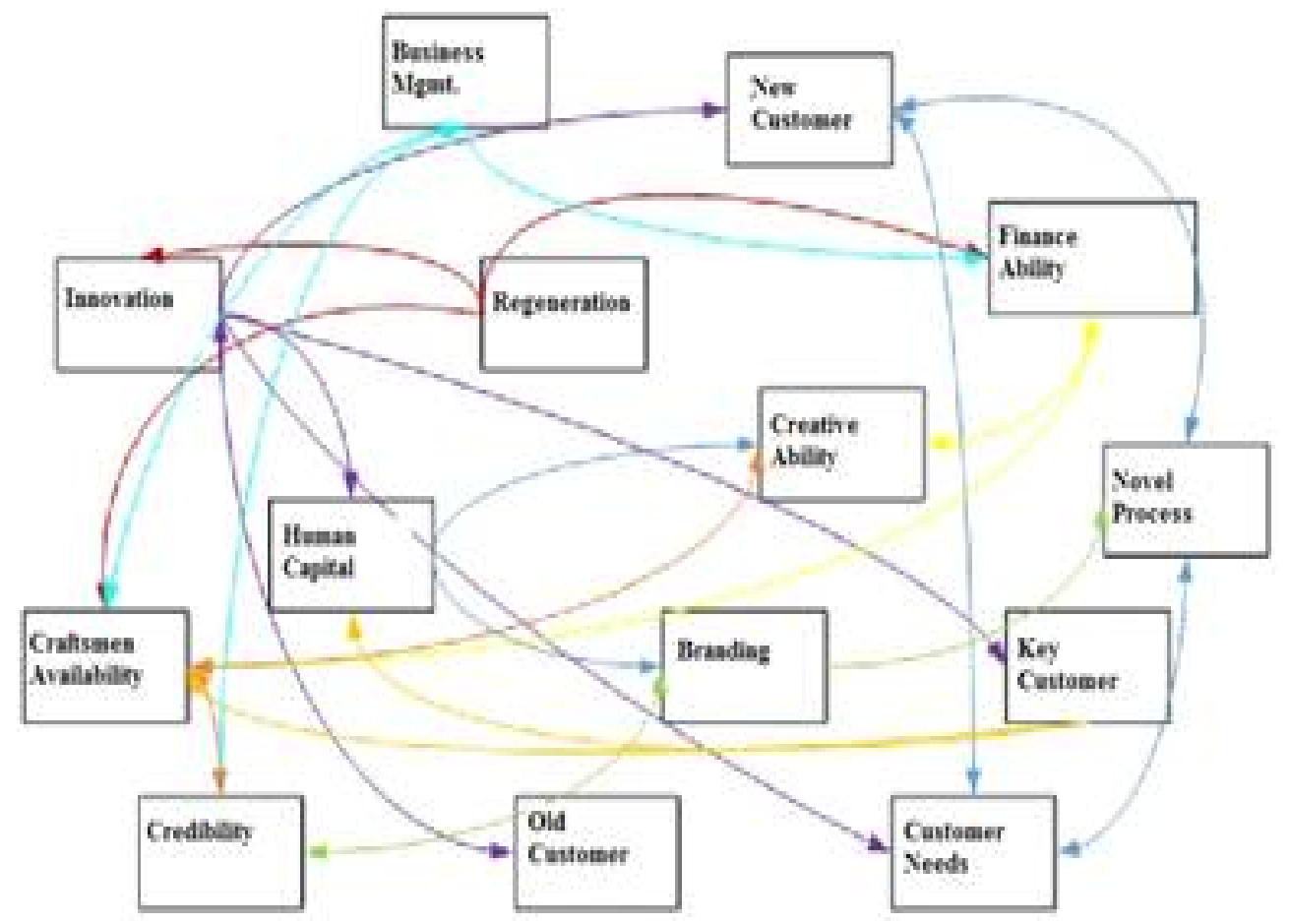

Figure 1. Impact Relation Map of Marketing Criteria for Batik Madura SMEs

Source: Processed primary data, 2018

ability and innovation. SMEs' human capital influences creative ability, innovation and customer loyalty. Every other arrows indicates the criteria that affects another criteria and so on.
The development of the ANP model was based on the network model along with the influential criteria of marketing strategy alternatives. Figure 2 shows the model of Batik Madura SMEs marketing strategy selection criteria.

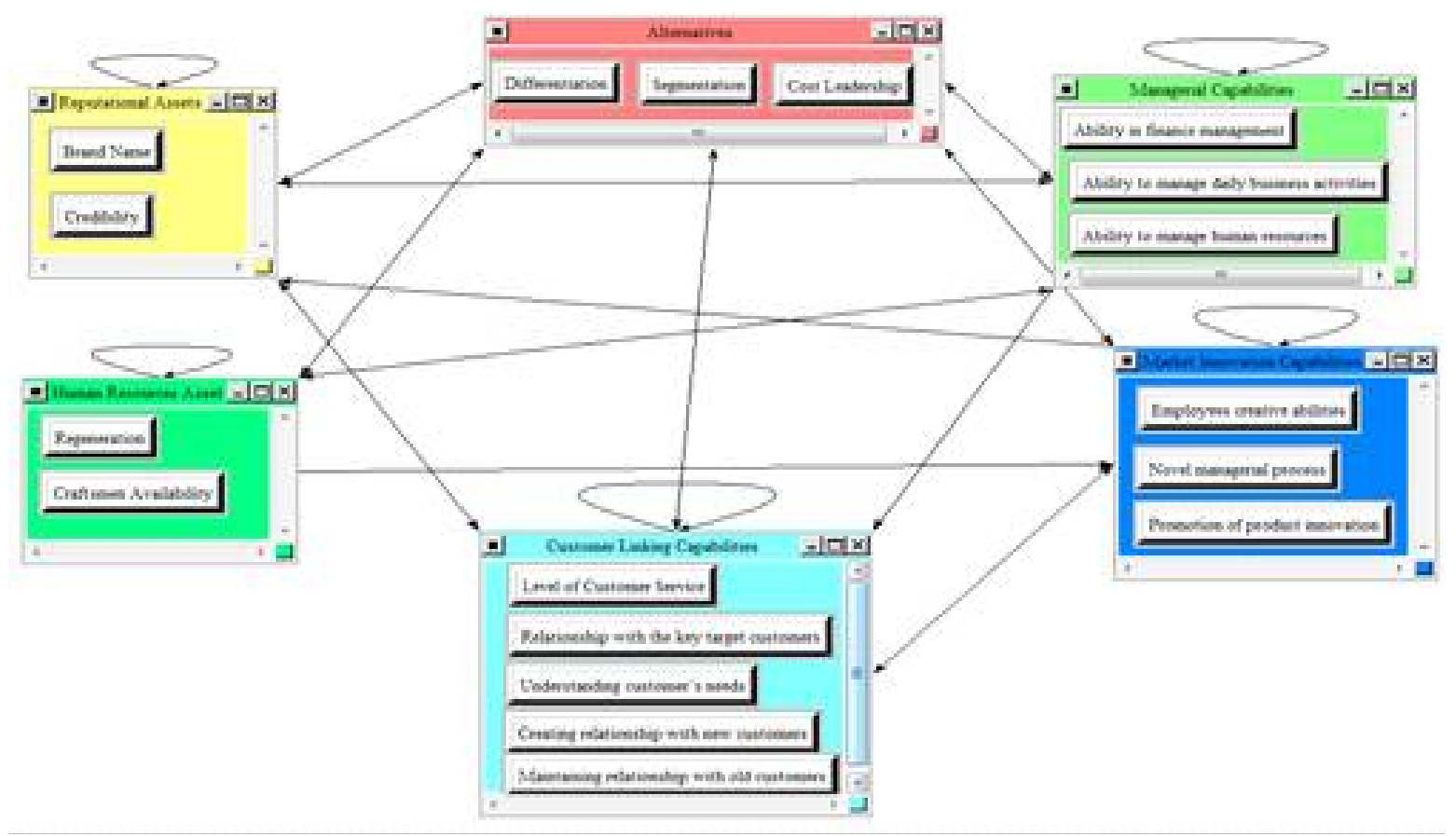

Figure 2. The ANP model for Batik Madura SMEs

Source: Processed primary data, 2018 
Under each of the individual criteria, the geometric means value of the marketing alternatives was calculated and the ANP supermatrix was constructed using Super Decision Software. After performing the first step of ANP which is the network structure formation. DEMATEL based
ANP were used to determine the values of the factor priority right after the consistency of comparison matrices and the un-weighted super matrix, the weighted super matrix and the limit super matrix are assured. Figure 2 shows examples of consistency examination using this specialized software.

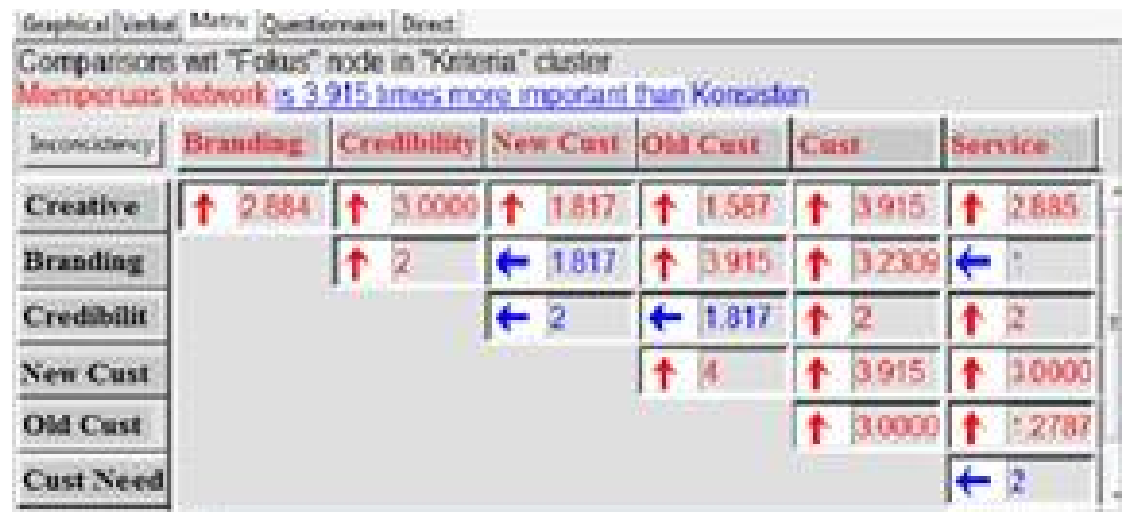

Fig. 2a. Example of DEMATEL-ANP consistency pairwise matrix comparisons Source: Processed primary data, 2018

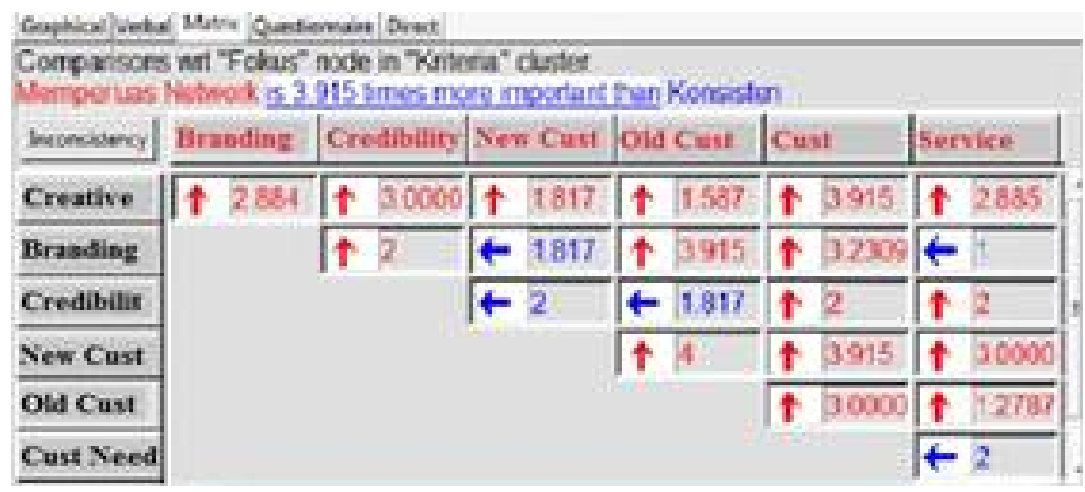

Fig. 2b. Example of DEMATEL-ANP consistency calculation

Source: Processed primary data, 2018

Next step is determining the relationship rate between criteria with the DEMATEL method. The following is the table of total influences given and received by each criteria.

Table 1. Influence on Each Criteria.

\begin{tabular}{lllll}
\hline Criteria & $\mathrm{R}$ & $\mathrm{c}$ & $(\mathrm{r}+\mathrm{c})$ & $(\mathrm{r}-\mathrm{c})$ \\
\hline Regeneration & 4,100 & 3,902 & 8,002 & 0,198 \\
Craftsmen avail & 4,754 & 4,517 & 9,271 & 0,237 \\
Innovation & 4,855 & 4,284 & 9,139 & 0,571 \\
Creative ability & 5,058 & 4,744 & 9,802 & 0,314 \\
Novel process & 4,929 & 5,126 & 10,055 & $-0,197$ \\
Finance ability & 4,317 & 4,146 & 8,463 & 0,171 \\
Business Mgmt. & 4,442 & 4,397 & 8,839 & 0,045 \\
Human capital & 4,212 & 3,953 & 8,165 & 0,259 \\
Customer service & 4,601 & 5,218 & 9,819 & $-0,617$ \\
New customer & 4,515 & 5,596 & 10,111 & $-1,081$ \\
Key Customer & 5,226 & 5,125 & 10,351 & 0,101 \\
Old Customer & 4,929 & 5,125 & 10,054 & $-0,916$ \\
Customer needs & 4,442 & 5,126 & 9,568 & $-0,684$ \\
Brand & 4,146 & 4,317 & 8,463 & 0,169 \\
Credibility & 4,744 & 5,058 & 9,802 & 0,313 \\
\hline Source: Processed
\end{tabular}

Source: Processed primary data, 2018 
Based on Table 1 above, it can be seen that the effort to innovate has the highest $(\mathrm{r}-\mathrm{c})$ value of 0.571 . This means that this criteria is a criteria that has most influence than any other criteria. Conversely the most negative $(\mathrm{r}-\mathrm{c})$ value is -1.081 on the criteria for expanding to new customer. This means that this criteria more likely to be affected than any other influences. The weights of each column in the degree of relative impact for evaluation criteria were normalized to get relative importance weights. Then, every element in a column was divided by the sum of that column. In the last DEMATEL step, the results from the previous step were synthesized to give the interdependence priorities of the criteria.
Thus, the weights of the evaluation criteria can be determined as shown in Table 2.

In last phase, the TOPSIS methodology used the DEMATEL based ANP methodology results as input to calculate each selection criteria's preference value for choosing a marketing strategy. The marketing strategies in the Batik Madura SMEs are a more focused marketing (FS), cost-conscious marketing (CC), differentiation marketing (DS) or customer-networked marketing strategies (CS). Based on the weight of each criteria, priority can be given to the marketing strategy. This means that the greater the weight the greater the priority given to the related marketing strategy.

Table 2. The Criteria Weight

\begin{tabular}{ll}
\hline Criteria & Weight \\
\hline Regeneration & 0.090078 \\
Craftsmen avail & 0.091677 \\
Innovation & 0.105365 \\
Creative ability & 0.094832 \\
Novel process & 0.073890 \\
Finance ability & 0.088972 \\
Business Mgmt. & 0.083808 \\
Human capital & 0.092578 \\
Customer service & 0.056678 \\
New customer & 0.037662 \\
Key Customer & 0.086103 \\
Old Customer & 0.044424 \\
Customer needs & 0.053932 \\
Brand & 0.088969 \\
Credibility & 0.094825 \\
\hline
\end{tabular}

Source: Processed primary data, 2018

All cases are calculated up to now except weight of interrelations between indexes. In order to obtain results of weight blocks needed for estimating weights of interrelations between indexes of the five main criteria, customer networking (SCN), innovation capabilities (SIC), managerial competency (MAC), human capital (HRC), and company reputation (SCR). The weights of the criterion are obtained by applying equations (3) to (8) to calculate the limiting power of the weighted super matrix until a steady-state condition is achieved.

Table 3 shows the limited super matrix demonstrating the main criteria.

Table 3. Example of the Limited Super Matrix

\begin{tabular}{llllll}
\hline & MAC & SIC & SCN & HRA & SCR \\
\hline MAC & 0,0403 & 0,0403 & 0,0403 & 0,0403 & 0,0403 \\
SIC & 0,2008 & 0,2008 & 0,2008 & 0,2008 & 0,2008 \\
SCN & 0,0584 & 0,0584 & 0,0584 & 0,0584 & 0,0584 \\
HRA & 0,1256 & 0,1256 & 0,1256 & 0,1256 & 0,1256 \\
SCR & 0,0747 & 0,0747 & 0,0747 & 0,0747 & 0,0747 \\
\hline \multicolumn{5}{l}{ Source: Processed primary data, 2018 }
\end{tabular}

The results of Table 3 demonstrate that the most concerned by the decision maker is innovation (0.076) and creative ability (0.065), and the least concerned by the experts is customer service and expanding to new customer (0.022). From the standpoint of the dimensions, the important dimension 
among the five dimensions is SMEs innovation capability, and the promotion of innovation as important criteria, the second is human resources asset, and the criterion of regeneration as well as creative ability. This finding revealed that decision maker should consider SMEs innovation capability when selecting their marketing strategy.

The TOPSIS method is started by using eqs. (9) until (12), in which the weights of the criteria are derived from the DEMATEL calculation. Using equations (11) and (12), the ideal solution ( $\mathrm{A}^{*}$ ) as well as the nadir solution (A-) can be obtained. The positive ideal solution determines the best value of each selection criteria in the selected strategy, whereas the lowest value of each selection criteria is shown by the value of the negative ideal solution.

By using eqs. (13), (14) and (15), each alternative from the ideal and nadir solutions are separated, and the relative closeness to the ideal solution are calculated. The computed distance of each marketing strategy from ideal solution $(\mathrm{Si}+i)$, negative solution $(\mathrm{Si}-$ ) and relative closeness $(R C)$ are shown in Table 4 below.

Table 4. The Final Ranking of Marketing Strategy

\begin{tabular}{lccll}
\hline Strat & $S_{i}^{+}$ & $S_{i}^{-}$ & $\mathrm{RC}$ & Rank \\
\hline CC & 0,138 & 0,179 & 0,563 & 2 \\
FS & 0,132 & 0,187 & 0,586 & 1 \\
DS & 0,246 & 0,024 & 0,089 & 3 \\
CS & 0,281 & 0,027 & 0,087 & 4 \\
\hline
\end{tabular}

Source: Processed primary data, 2018

Based on the Relative Closeness value, it was concluded that the ranking of the Batik Madura marketing strategy to be a more focused marketing strategy (FS), followed by cost-conscious marketing (CC), differentiation marketing (DS) then lastly the customer-networked people-based marketing strategy (CS). Cost conscious marketing means that the company needs to produce large volume of products to take advantage of the market scale and customer experience. Differentiation marketing is a strategy that is carried out so that companies can distinguish their products from their competitors and get premium price for their uniqueness. Customernetworked people-based marketing strategy is a strategy through community networks. The strategy is a staple to involve various parties that communicate with each other through online and offline media and strengthen the company's relationship with consumers.

Batik Madura has its uniqueness, in color, style and philosophy behind their beautiful patterns that come from Madura people's own local wisdom. Focused marketing strategy is about how put batik Madura as the local cultural products right into the established market segment. Batik Madura SMEs managers should map their market segment, so that they would know each market segment's potential. The managers could start from determining the target market that has strong interests in using batik. By focusing on the market segment with strongest interest in batik, batik Madura SMEs can easily adjust their batik motifs or style that match with the characteristics of the target market segment. Furthermore, batik Madura SMEs can effectively allocate and manage their resources to fulfill the demand of the selected segments. Therefore, focused marketing strategy will be suiTable to increase the competitiveness and become the basis for building competitive advantages of batik Madura SMEs.

\section{CONCLUSION}

Based on the Relative Closeness value, it was concluded that the ranking of the Batik Madura marketing strategy to be a more focused marketing strategy (FS), followed by cost-conscious marketing (CC), differentiation marketing (DS) then lastly the customer-networked people-based marketing strategy (CS). Cost conscious marketing means that the company needs to produce large volume of products to take advantage of the market scale and customer experience. Differentiation marketing is a strategy that is carried out so that companies can distinguish their products from their competitors and get premium price for their uniqueness. Customernetworked people-based marketing strategy is a strategy through community networks. The strategy is a staple to involve various parties that communicate with each other through online and offline media and strengthen the company's relationship with consumers.

Batik Madura has its uniqueness, in color, style and philosophy behind their beautiful patterns that come from Madura people's own local wisdom. Focused marketing strategy is about how to put batik Madura as the local cultural products right into the established market segment. Batik Madura SMEs 
managers should map their market segment, so that they would know each market segment's potential. The managers could start from determining the target market that has strong interests in using batik. By focusing on the market segment with strongest interest in batik, batik Madura SMEs can easily adjust their batik motifs or style that match with the characteristics of the target market segment. Furthermore, batik Madura SMEs can effectively allocate and manage their resources to fulfill the demand of the selected segments. Therefore, focused marketing strategy will be suitable to increase the competitiveness and become the basis for building competitive advantages of batik Madura SMEs.

\section{REFERENCES}

Cahyadi I. 2016. Tantangan Internasionalisasi UKM di Indonesia dalam Menghadapi Masyarakat Ekonomi ASEAN. Kajian, (20) 2

Danis W.M., Chiaburu D.S. and Lyles M.A. 2010. The Impact of Managerial Networking Intensity And Market-based Strategies on Firm Growth during Institutional Upheaval : A Study of Small and Medium-sized Enterprises in a Transition Economy. Journal of International Business Studies, (41) : 287-307.

De Jong J.P.J. and Hulsink W. 2012. Patterns of Innovating Networking in Small Firms. European Journal of Innovation Management, (15) $3: 280-297$.

Ernst H., Wayne D. H. and Carsten R. 2010. Sales, Marketing, and Research-and-Development Cooperation Across New Product Development Stages : Implications for Success. Journal of Marketing, (74) 5: 80-92.

Fontela E. and Gabus A. 1974. DEMATEL : Innovative Methods, Report no. 2, Structural Analysis of the World Problematique. Battelle Geneva Research Institute.

Halim H.A., Ahmad N.H., Ramayah T. and Hanifah H. 2014. The Growth of Innovative Performance among SMEs : Leveraging on Organisational Culture and Innovative Human Capital. Journal of Small Business and Entrepreneurship Development, (2) 1: 107-125.

Hooley G.J., Greenley G.E., Cadogan J.W. and Fahny J. 2005. The Performance Impact of Marketing Resources. Journal of Business Research, (58) 1: 18-27.

Hwang C. L. and Yoon K. 1981. Multiple Attribute Decision Making - Methods and Applications: A State of the Art Survey, Springer Verlag.

Kazlauskaitë R., Autio E., Gelbûda M. and Đarapovas T. 2015. The Resource-based View and SME Internationalisation : An Emerging Economy Perspective. Resource, (3) 2.

Lin C.T., Lee C., Wu C.S. 2009. Optimizing a Marketing Expert Decision Process for the Private Hotel. Expert Systems with Applications, (36) $3: 5613-5619$.

Lo, W.S., and Hong, T.P. A three-level multiple-agent early warning mechanism for preventing loss of customers in fashion supply chain management, Industry and Business Analysis, IGI Global, 2012 pp. 173-184.

Marek P. 2014. A Critical Analysis of the Concept of Marketing Strategies for Small and Midsized Companies. Economics : Management and Financial Markets, (9) 4: 255.

MohagharA., FathiM. R., SasaniA. and Khanmohammadi E. 2012. Integration of Linear Goal Programming and Fuzzy VIKOR Method for Marketing Strategy Selection: A Case Study. Journal of American Science, (8) 6: 827-834.

O'Cass A. and Ngo L. 2012. Creating Superior Customer Value for B2B Firms through Supplier Firm Capabilities. Industrial Marketing Management, (41) : 125-135.

Saaty T.L. 1996. Decision Making with Dependence and Feedback : Analytic Network Process. RWS Publications, Pittsburgh.

Saaty T.L. and Vargas L.G. 1996. Diagnosis with Dependent Symptoms : Bayes Theorem and The Analytic Hierarchy Process. Operations Research, (46) 4 : 491-502.

Sengupta A., Venkatesh D.N. and Sinha A. 2013. Developing Performance-linked Competency Model : A Tool for Competitive Advantage. International Journal of Organizational Analysis, (21) 4: 504-527.

Soekesi A.E.M. 2013. Karakteristik UKM Batik Pada Klaster Batik Di Jawa Tengah. Seri Kajian Ilmiah, (15) 1: 63-70.

Sok P. and O'Cass A. 2011. Achieving Superior Innovation-based Performance Outcomes in SMEs through Innovation Resource-Capability Complementarity. Industrial Marketing Management, (40) $8:$ 1285-1293.

Suliyanto, Wulandari S.Z. and Novandari W. 2010. Competitive Strategy Model for Purbalingga Batik. Economic Journal of Emerging Markets, (2) $2: 169-185$.

Van den Bulte C. 2010. Opportunities and Challenges in Studying Customer Networks. London, Routledge.

Wu C.S., Lin C.T. and Lee C. 2010. Optimal Marketing Strategy: A Decision-Making with ANP and TOPSIS. International Journal of Production Economics, (127) $1: 10190-196$. 